\title{
Strategy of Action of Uzbekistan on the Development of Export of Textile Products
}

\section{Humoyun Qodirov*}

Department of Engineering, Namangan Institute of Engineering and Technology, Uzbekistan

\begin{abstract}
The article examines the theoretical and practical aspects of the Strategy of Uzbekistan's actions in the development of the export of textile products. It analyzes: the export potential of the republic; strategies of «UZTEKSTILPROM» used for the development of the international textile market; modern directions of development of marketing strategies for the development of textile innovations, branding, fashion industry, product design, international quality standards, etc. are disclosed. Suggestions for further diversification of the sewing and knitting assortment of exported products and developing the textile market of the European Union and other countries are recommended.
\end{abstract}

Keywords: Export potential; IT technology; Design development; National brand; Branding; Fashion industry

\section{Introduction}

Although Uzbekistan ranks sixth in the world in production of cotton fiber, and the third in its exports, and its share in cotton yarn is less than one percent. The Uzbek textile industry has a competitive cost advantage: labor, energy, water, and the availability of raw materials. The share of the textile, garment and knitwear industry is only $4.6 \%$ of the country's GDP, while the competitiveness of high value-added products remains low. For example, in the «UZTEKSTILPROM» system, the share of the garment and knitwear industry is less than $20 \%$, while the share of the garment industry is about $10 \%$. The main reasons for this situation are: the lack of domestic fabrics, their low quality; low power of dyeing and finishing production; the presence of serious trade preferences of competing countries in the domestic and foreign textile markets. As a result, the competitiveness of our finished garments and knitwear in the domestic and world markets remains weak. Based on the above, the Strategy for further development of the Republic of Uzbekistan in 2017-2021 provides for: "mastering the production of fundamentally new types of products and technologies, ensuring on this basis the competitiveness of domestic goods in foreign and domestic markets".

For the purposes of the practical implementation of this priority in the field of textile industry 14.12.2017 was adopted a special Presidential Decree "On measures to accelerate the development of textile and garment and knitwear industry" which identified a set of priority measures to solve existing problems, as well as the expansion of the production of high-quality products and their promotion to world markets. This decree defines the enhancement of the role of the textile industry in the economy on the basis of an increase in the production of high value-added goods by reorienting enterprises in the industry towards accelerated development of high-tech industries; transition to a new quality management system and IT technologies, direct assistance to eliminate old stereotypes in this matter; provision of timely information on the conjuncture of the domestic and foreign markets, as well as their forecasts; the formation of a cluster model integrating all processes starting from the production of raw cotton, its primary processing and to the production of finished goods with high added value; the development of logistics, engineering infrastructure, the choice of optimal directions in transportation, as well as the improvement of the tariff system of freight; expanding exports of high-quality finished textile products, based on the use of innovative technologies, know-how, design developments and the introduction of national brands to world markets.

The purpose of this study is to analyze the export processes of textile and garment and knitwear products in Uzbekistan and identify ways to use marketing strategies to develop new markets.

\section{Research objectives}

The study of total exports and its geography, as well as the assortment structure; comparative characteristics of the textile export strategies in Uzbekistan and in foreign countries; identification of opportunities for the introduction of Uzbek brands of garments and knitwear products to the markets of the European Union and other countries.

\section{Analysis of Literature on the Topic}

The founders of export theory, including international trade, are A. Smith and D. Ricardo. Adam Smith for the first time developed a theoretical model in which the theory of "Absolute Excellence" was substantiated, and David Ricardo, developing this theory, substantiated the model of "Relative Excellence" in international trade [1]. Stuart Mill, in turn, supplemented the theory of D. Ricardo with the following ideas $[2,3]$. In international trade, the price is formed on the basis of supply and demand, and each country must have solvency. The Swedish teachings E. Herschel and B. Olin, in their turn [4], in the 30s of the 20th century, exploring the numerous factors influencing the volume and structure of international trade, substantiated the concept of the production factor affecting exports from each country. P. Samuelson developed the mathematical apparatus of this concept [5]. V. Leontev, in his theoretical studies, came to the conclusion that in 1947, the American economy did not develop along the path of export of capitalintensive goods [6], but the export of labor-consuming goods prevailed in the country. M. Porter, an American scientist summarizing existing

*Corresponding author: Humoyun Qodirov, Department of Engineering, Namangan Institute of Engineering and Technology, Uzbekistan, Tel: +998901480117; E-mail: x.kadirov92@mail.ru

Received October 04, 2018; Accepted November 28, 2018; Published December 07, 2018

Citation: Qodirov H (2018) Strategy of Action of Uzbekistan on the Development of Export of Textile Products. J Account Mark 7: 301. doi: 10.4172/2168-9601.1000301

Copyright: ( 2018 Qodirov H. This is an open-access article distributed under the terms of the Creative Commons Attribution License, which permits unrestricted use, distribution, and reproduction in any medium, provided the original author and source are credited. 
models and theories of foreign trade of companies, developed a theory of competition in international markets based on five forces [7].

In Uzbekistan, M. R. Boltaboev, Z. D. Odilova, R. Rakhmonov, U. Maraimova, D. Mirzakhalilova, S. Azam, Be Young Song, G. Karieva, U. Rasulov and I. Khaliqova have investigated export problems as an object of dissertations for the degree of Doctor and Candidate of Economic Sciences [8-14]. These studies have developed models of marketing strategies, methods for assessing the competitiveness of textile enterprises, and their ratings, methods of macro and micro segmentation in international markets, etc. However, these studies are mainly devoted to solving macro problems of the industry. They do not reflect the issues of improving the competitiveness of garments and knitwear and the peculiarities of their export to selected regional international markets: the application of new marketing strategies, the development of branding, the further diversification of the range and other new modern requirements.

\section{Methodology of the Study}

In this study, a systematic methodological approach was chosen based on marketing (desk, field and panel, as well as econometric) methods. The export potential of an enterprise is examined in terms of determining their ability to further diversify the range, use market information, apply marketing tools, methods and strategies for deep penetration into selected foreign markets, as well as achieving the necessary economic efficiency.

\section{Analysis and Research Results, as well as their Discus- sion}

The textile industry of Uzbekistan is among the fastest growing sectors of the national economy. The privileges and preferences provided for local producers allowed for a short time to establish in the country the production of not only the primary range - cotton yarn, harsh fabrics and knitted fabrics, but also ready-made garment and knitwear products that meet international standards and make a worthy competition to foreign analogues. Currently, more than 7,300 textile enterprises operate in Uzbekistan, of which more than 1,300 are merged into the «UZTEKSTILPROM» Association, including 210 spinning, 114 weaving, 38 wadded and 26 non-woven industries, 4,800 garment factories. The enterprises have a processing capacity of 710 thousand tons of cotton fiber and produce 1253 million square meters of fabrics of various assortments.
The leading enterprises of the industry are FE LLC "Daewoo Textile", JV LLC "Indorama Kokand Textile", JV LLC "Uztex group", FE LLC "LT International", LLC "Surhontex", LLC "Mergan Textile", "Urganch Bahmal”, LLC "Osborn Textile”, LLC "Oq saroy Textile", LLC "Jizzah Toqimachi”, OOO "Quva Tekstil”, LLC "Horazm Tech" and many others.

Uzbekistan has a stable resource base, energy and labor resources. All this makes it possible to regularly commission modern textile complexes with foreign partners, which ensure a steady increase in the production of high value-added products. For the period from 1991 to 2018 , the volume of internal processing of cotton fiber increased from $7 \%$ to $58 \%$.

Over the past ${ }^{1} 0$ years, the production capacity of textile enterprises has been updated by $100 \%$. Installed equipment of the last generation which contributes to improving product quality and increasing its competitiveness in the global market.

Access to $100 \%$ natural raw materials in Uzbekistan and ensuring the production of the most modern equipment, as well as the development of advanced technologies make it possible to produce completely environmentally friendly products.

The rapid growth of the textile industry has influenced the development of its own fashion industry, strengthening the role of Uzbekistan as one of the cultural centers of the world. A wide class of consumers appeared in the country, giving preference to environmentally friendly, high-quality and fashionable fabrics and clothing, which served as an impetus for the flow of well-known world brands into the country. Only in 2017, the enterprises of the industry mastered more than 210 new models of finished garments and knitwear. According to experts, much remains to be done to develop the significant potential that lies in the light industry of the republic. In the near future, it will retain a key role in the development of industrial production in the republic, and according to world experts, in the future Uzbekistan should become one of the largest in the world of manufacturers of textile products (Figure 1).

As can be seen from the indicators of Table 1, in 2025, clothes, woven fabrics, knitwear and, accordingly, the volume of their exports, will almost double in the Republic. Serious changes will also occur in the structure of production of textile goods (Table 2).

In accordance with the Decree of the President of the Republic of

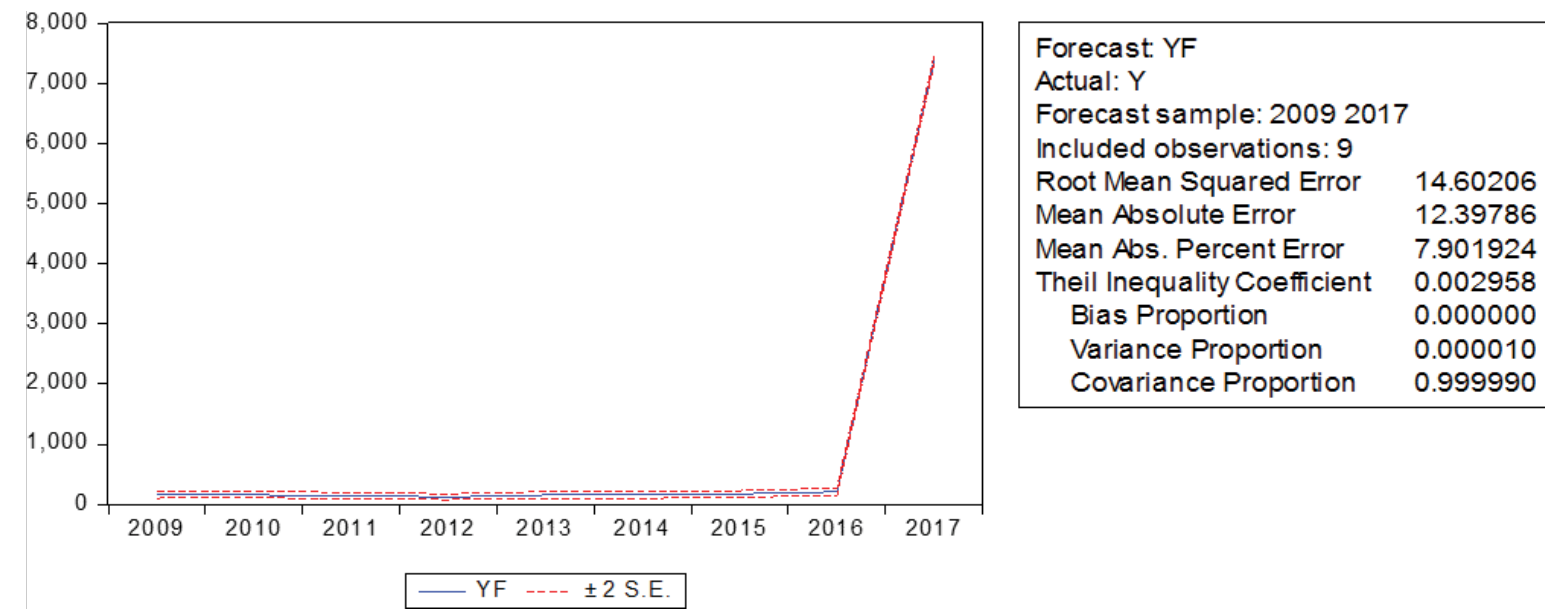

Figure 1: All parameters are significant based on Mape and TIC criteria. 
Uzbekistan "On measures to accelerate the development of textile and garment and knitwear products", the Association «UZTEKSTILPROM» was established, consisting of 1,300 enterprises, with an export potential of $\$ 1.6$ billion and an investment volume of $\$ 3.1$ billion (Table 3 ).

\section{The structure of «UZTEKSTILPROM»}

- Textile sector (cotton yarn, fabric)

- Sewing and knitting sector (clothing, knitwear)

- Mechanical Engineering (“RIETER-UZBEKISTAN”, "METAL PROCESSING”)

Under the association «UZTEKSTILPROM» carry out activities

- Advertising and Marketing Agency

- Design center "Sharq liboslari"

- Exchange company "Uztextile Brok"

Starting from 2017, the Association «UZTEKSTILPROM» began to actively participate in international exhibitions under a single national stand "Made in Uzbekistan" at exhibitions in Russia, the EU, and the USA. The Joint Protocol on Cooperation between the EU and Uzbekistan has been ratified.

\section{Under the leadership of the Association «UZTEKSTILPROM»} only in 2018

- The creation of cotton-textile clusters in 13 regions of the country has begun;

- Export of textile products is carried out under a single labeling «UZtextile»;

- Held in the first "International Textile Conference of Uzbekistan" and "International Exhibition of Textiles and Fashion Industry” UzTextile Expo 2018 “.

«UZTEKSTILPROM» develops Partnership Relations with ITMF - International Textile Manufacturers Federation, KOFOTI (Korea), KITECH (Korea), CITI (India), IFC (IFC), Gerzi (Switzerland), Rieter
(Switzerland), Strategy Partners (Russia), Indorama Corp. (Singapore), Jinsheng Group (China), Deloitte Touche Tohmatsu (USA).

The priority directions of «UZTEKSTILPROM» are integration of IT with the control system; personnel training system; standardization and certification; promotion of a national brand; research and development; cluster system development; government support-the proportion of GDP growth.

As the main priority measures to achieve the main objectives are identified: the implementation of 170 projects. Among them: new projects-119; modernization and expansion-51 with a cost of more than 3.8 billion dollars, which will provide an increase in the export potential of textiles to 7.1 billion US dollars and the creation of 94 thousand new jobs. At the same time, the processing of cotton yarn will be focused on the production of technologically innovative and environmentally friendly products.

At the same time, a single brand «UZtextile», e-commerce, online trading is being developed. Logistics systems are being created and developed, as well as product placement in international markets.

Promotion of the national brand «UZtextile» to international markets is planned for off-line advertising - TV, radio, newspapers/ magazines, online advertising through social networks, mailing lists, etc.

For the development of international cooperation, «UZTEKSTILPROM» plans to create regional offices and branches abroad in Germany, Belgium, Turkey, Russia, Belarus, Azerbaijan, R. Korea, Japan and China.

Currently, Uzbek textile products are exported to more than 55 countries of the world. The main export markets are the CIS countries, primarily Russia, as well as the countries of Latin America, the EU, the Republic of Korea, China, Singapore, Iran, Israel, the USA and others. In 2018, new markets were developed - Pakistan, Georgia, Croatia, Nigeria and a number of others; Russia and the CIS countries are the largest importers of Uzbek textile enterprises. They account for more than $51 \%$ of all shipments, $21 \%$ are exported to South Asian countries, over 12\% to Europe, $8 \%$ to the Middle East and Africa (Table 4).

\begin{tabular}{|c|c|c|c|}
\hline No & Indicators & Average term (until 2020) & Long term (until 2025) \\
\hline $\mathbf{1}$ & Industrial production & 180 & 350 \\
\hline $\mathbf{2}$ & Clothing and fabrics & 190 & 300 \\
\hline $\mathbf{3}$ & Knitwear, socks & 260 & 450 \\
\hline $\mathbf{4}$ & Export & & 470 \\
\hline
\end{tabular}

Table 1: The expected growth of garment and knitwear production in Uzbekistan $(2017=100 \%)$.

\begin{tabular}{|c|c|c|c|}
\hline No & Indicators & $\mathbf{2 0 1 8}$ \\
\hline & & $\mathbf{2 0 2 5}$ \\
\hline $\mathbf{1}$ & including: Cotton yarn & 59 & $\mathbf{1 0 0}$ \\
\hline $\mathbf{2}$ & Knitted fabric & 8 & $\mathbf{3}$ \\
\hline $\mathbf{4}$ & Fabric & 16 & 16 \\
\hline $\mathbf{5}$ & clothing & 16 \\
\hline
\end{tabular}

Table 2: Expected structural changes in the production of textile goods in Uzbekistan until 2025 (At \%).

\begin{tabular}{|c|c|c|c|}
\hline Strengths & Weaknesses & Opportunities & Threats \\
\hline $\begin{array}{l}\text { Internal: } \\
\text { - Internationally recognized cotton / yarn } \\
\text { quality; } \\
\text { - Competitive labor / energy costs; } \\
\text { - Proximity to the markets of the CIS, } \\
\text { Central Asia and Europe. }\end{array}$ & $\begin{array}{l}\text { - Lack of artificial and synthetic raw } \\
\text { materials; } \\
\text { - Underdeveloped: fashion industry, } \\
\text { centers for marketing research; networks } \\
\text { of advertising agencies, engineering } \\
\text { services, etc. }\end{array}$ & $\begin{array}{l}\text { - Competitive market for the main cotton } \\
\text { product and high export capacity. }\end{array}$ & $\begin{array}{l}\text { External: } \\
\text { - The presence of strong competitors } \\
\text { like China, Turkey, India, R. Korea and } \\
\text { others. }\end{array}$ \\
\hline
\end{tabular}

Table 3: SWOT analysis of the textile industry in Uzbekistan. 
Citation: Qodirov H (2018) Strategy of Action of Uzbekistan on the Development of Export of Textile Products. J Account Mark 7: 301. doi: 10.4172/21689601.1000301

Page 4 of 5

In the export structure of Uzbekistan, woven, non-woven and knitted fabric is $7 \%$, ready-made knitted clothing and hosiery products, carpets, terry products- $48 \%$, and cotton, mixed and synthetic yarn- $45 \%$.

Today, there are about 70 trading houses of textile enterprises of Uzbekistan abroad. Over the past few years, foreign investment in the textile industry of Uzbekistan has amounted to more than $\$ 3.1$ billion.
Over $80 \%$ of foreign investment attracted to such countries as South Korea, Switzerland, Singapore, Great Britain, Germany, India and Turkey.

The quality management system ISO-9001 has been implemented at more than 600 enterprises of the "UZTEKSTILPROM» Association.

The implementation of the QMS at the Association's enterprises

\begin{tabular}{|c|c|c|c|c|c|c|c|}
\hline Years & $\begin{array}{c}\text { Net income } \\
\text { (million UZS), Y }\end{array}$ & $\begin{array}{c}\text { Total costs (million } \\
\text { UZS), X1 }\end{array}$ & $\begin{array}{l}\text { Personnel with a higher } \\
\text { education (person), X2 }\end{array}$ & $\begin{array}{l}\text { Net receipts } \\
\text { (million UZS), X3 }\end{array}$ & $\begin{array}{l}\text { Investments in fixed } \\
\text { assets (million UZS), X4 }\end{array}$ & $\mathbf{t}$ & Profitability \% \\
\hline 2009 & 141,6 & 3585,5 & 10 & 6577,5 & 253,3 & 1 & 3,9 \\
\hline 2010 & 145,8 & 4259,6 & 13 & 7513,3 & 276,4 & 2 & 3,4 \\
\hline 2011 & 149,2 & 5606,5 & 15 & 8449,1 & 298,1 & 3 & 2,7 \\
\hline 2012 & 150,7 & 6917 & 16 & 9184,9 & 304,5 & 4 & 2,2 \\
\hline 2013 & 163,4 & 7627,5 & 19 & 9720,7 & 346,2 & 5 & 2,1 \\
\hline 2014 & 172,3 & 9638 & 19 & 10256,5 & 401,3 & 6 & 1,8 \\
\hline 2015 & 155,2 & 10872 & 23 & 11224,8 & 425,6 & 7 & 1,4 \\
\hline 2016 & 196 & 13730,2 & 24 & 14175,7 & 964 & 8 & 1,4 \\
\hline 2017 & 7389,9 & 28892,3 & 22 & 29940,8 & 23648,1 & 9 & 25,6 \\
\hline & & & Net income (million UZS), Y & $\begin{array}{c}\text { Total costs (million } \\
\text { UZS), X1 }\end{array}$ & $\begin{array}{l}\text { Personnel with a higher } \\
\text { education (person), } \mathrm{X} 2\end{array}$ & Net receipts & $\begin{array}{c}\text { Investments in fixed } \\
\text { assets }\end{array}$ \\
\hline \multicolumn{3}{|c|}{ Net income (million UZS), Y } & 1 & & & & \\
\hline \multicolumn{3}{|c|}{$\begin{array}{c}\text { Total costs } \\
\text { (million UZS), X1 }\end{array}$} & 0,910961831 & 1 & & & \\
\hline \multicolumn{3}{|c|}{ Personnel with a higher education (person), X2 } & 0,329366343 & 0,675486715 & 1 & & \\
\hline \multicolumn{3}{|c|}{ Net receipts } & 0,952610741 & 0,691330672 & 0,586807477 & 1 & \\
\hline \multicolumn{3}{|c|}{ Investments in fixed assets (million UZS), X4 } & 0,999760722 & 0,718074705 & 0,343729487 & 0,758181348 & 1 \\
\hline \multicolumn{8}{|c|}{ Proven results on Eviews program } \\
\hline \multicolumn{3}{|c|}{ R-squared } & 0.999959 & \multicolumn{3}{|c|}{ Mean dependent var } & 962.6778 \\
\hline \multicolumn{3}{|c|}{ Adjusted R-squared } & 0.999917 & \multicolumn{3}{|c|}{ S.D. dependent var } & 2410.266 \\
\hline \multicolumn{3}{|c|}{ S.E. of regression } & 21.90308 & \multicolumn{3}{|c|}{ Akaike info criterion } & 9.311313 \\
\hline \multicolumn{3}{|c|}{ Sum squared resid } & 1918.98 & \multicolumn{3}{|c|}{ Schwarz criterion } & 9.420882 \\
\hline \multicolumn{3}{|c|}{ Log likelihood } & -36.90091 & \multicolumn{3}{|c|}{ Hannan-Quinn criter. } & 9.074863 \\
\hline \multicolumn{3}{|c|}{ F-statistic } & 242.1762 & \multicolumn{3}{|c|}{ Durbin-Watson stat } & 1.82427 \\
\hline \multicolumn{3}{|c|}{ Prob(F-statistic) } & 0 & & & & \\
\hline $314,6+$ & $07^{\star} \times 1+16,3^{\star} \times 2-0$ & $4^{*} \times 3+0,4^{*} \times 4$ & & & & & \\
\hline
\end{tabular}

Table 4: LLC "NIL-GRANIT" Andijan region.

\begin{tabular}{|c|c|c|c|c|c|c|c|c|}
\hline \multirow[b]{2}{*}{$\begin{array}{l}\text { ENTERPRISES AND INDICATORS OF THEIR } \\
\text { ECONOMETRIC ANALYSIS MODEL }\end{array}$} & \multirow[b]{2}{*}{ 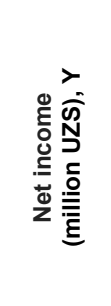 } & \multirow[b]{2}{*}{ 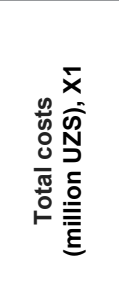 } & \multirow[b]{2}{*}{ 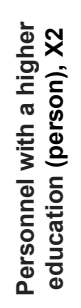 } & \multirow[b]{2}{*}{ 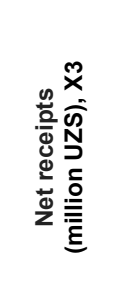 } & \multirow[b]{2}{*}{ 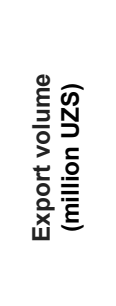 } & \multirow[b]{2}{*}{ 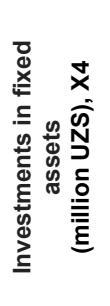 } & \multicolumn{2}{|c|}{ Profitability } \\
\hline & & & & & & & 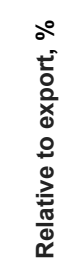 & 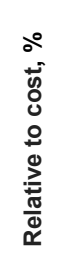 \\
\hline $\begin{array}{c}\text { LLC «NIL-GRANIT» } \\
Y=314,6+0,007^{\star} \times 1+16,3^{*} X 2-0,4^{\star} X 3+0,4^{*} X 4\end{array}$ & 7389,9 & 28892,3 & 22 & 29940,8 & 24847,1 & 23648,1 & 29,7 & 3,9 \\
\hline $\begin{array}{c}\text { FE LLC «KRAV TEKS» } \\
Y=-0,14^{*} X 1+36,7^{*} X 2+0,0007^{*} X 3+0,5^{*} X 4-463,8\end{array}$ & 20919,7 & 118543,6 & 9 & 115872,2 & 9933,6 & 9885,9 & 210,6 & 17,6 \\
\hline $\begin{array}{c}\text { LLC «NAMUNA» } \\
Y=-0,5^{*} X 1+221,6^{*} X 2+0,5^{*} X 3-208,8^{*} X 4-1974,9\end{array}$ & 176,7 & 24320,2 & 8 & 24589,4 & 25608,7 & 0 & 0,7 & 0,7 \\
\hline $\begin{array}{c}\text { LLC «KEZAR TEKS» } \\
Y=3216,7-0,6^{*} X 1+221,4^{\star} X 2+0,8^{*} X 3-8,4^{*} X 4\end{array}$ & $-3876,4$ & 18441,8 & 4 & 13820,7 & 2329,6 & 1128,6 & - & - \\
\hline $\begin{array}{c}\text { JV LLC «ИHBECT-TEКС» } \\
Y=1,64-0,04^{\star} X 1+0,4^{\star} X 2+0,05^{\star} X 3+0,0009^{*} X 4\end{array}$ & 85,3 & 6317,3 & 10 & 6409,4 & 1684,1 & 0 & 5,1 & 1,4 \\
\hline $\begin{array}{c}\text { РЕ «АЛ-ХАКИМ» } \\
Y=0,18^{*} X 1+33,9^{*} X 2+0,34^{*} X 3-13,6^{*} X 4-101,7\end{array}$ & 348,4 & 6094,6 & 5 & 6984,2 & 8440,4 & 0 & 4,1 & 5,7 \\
\hline $\begin{array}{c}\text { PЕ «ХЎЖАОБОД ФАЙЗ-М» } \\
Y=3292,7+0,8^{*} X 1+0,8^{*} X 2+0,13^{*} X 3\end{array}$ & 829,8 & 23815,9 & 0 & 24931,9 & 22568,6 & 10237,8 & 3,7 & 3,5 \\
\hline $\begin{array}{c}\text { LLC «ХЎЖАОБОД ФАЗО» } \\
Y=14,1+0,006^{*} X 1-0,4^{*} X 2+0,007^{*} X 3-0,03^{*} X 4\end{array}$ & 161,7 & 21389,9 & 3 & 22601,0 & 16735,1 & 4510,1 & 1,0 & 0,8 \\
\hline
\end{tabular}

Table 5: Econometric analysis of the export profitability of enterprises producing garments and knitwear in the Andijan region in 2017. 
is being conducted gradually, jointly by the staff of IP SGS Tashkent (Switzerland), IP TUV International Certification (Germany), IP Sert Management (Germany), IP QMS Italia (Italy), and JV "Uzbek-TurkTestmarkazi”. Also today 126 unit's standards are harmonized with international ISO standards. It is planned to harmonize 36 units in 2018 ISO International Standards. In order to determine the main factors affecting the export potential of enterprises and their profitability, we carried out an econometric analysis of the export activities of large LLCs of Andijan region, producing garments and knitwear (Table 5).

The result of the above analysis shows that the main factors affecting the export potential of an enterprise are the presence of highly qualified specialists, the volume of investments in fixed capital allocated for the modernization and development of new technologies and marketing strategies allowing for an increase in exports, as well as a decrease in costs.

\section{Conclusions and Recommendations}

As can be seen from the data Table 3, that the profitability of enterprises - exporters of garments and knitwear products is very low, in most cases it does not cover costs. The main reason for this situation is the export of garments and knitwear products of mass demand with an average price of 0.51 to 2.0 US dollars. According to our calculations, the critical profitability point for these enterprises for the export of garment and knitwear goods to the CIS countries is $15 \%$, and to Europe and the USA even higher.

However, Uzbekistan is developing experience in the development of the textile market with high value-added goods in Turkey, the European Union and the United States. For example, the companies "Istiqlol tekstil dizayn” LLC, "Impex Textiles Group" LLC, “Tukimachi Sanoat Textiles" LLC, "Asror Textiles Sanoat" LLC, "Sedat Triko Tashkent" LLC and others entered into these markets with their brands as "UZtex", "Samo", "Barchinoy Textile", "Al-Xakim", "Buka", "Turon", "Fazo-R", "Bahmal”, "Fayz-M”, etc.

This year, the representatives of «UZTEKSTILPROM» participated for the second time in New York at the International Textile Exhibition "TEX WORLD USA", where they held talks on the supply of Uzbek textile brands. The partners recommended the need to implement an international quality management system based on modern technologies and information and communication tools, as well as to expand the export geography. As a result, contracts for the supply of men's suits and shirts from Uzbekistan, as well as goods for hotels for 1 million US dollars were concluded at this exhibition. "Bek Mega Textile" and "American Green Baby" have signed an agreement for another \$ 1 million for the supply of colorful fabrics. In addition, a memorandum was signed on the establishment of the «UZTEKSTILPROM» pavilion in New York. Thus, the way is open for the Uzbek manufacturers in the American and other textile markets.
In our opinion, the Association «UZTEKSTILPROM» along with the foregoing progressive areas outlined for the near and distant future, it is necessary to pay special attention:

- To implement a policy of further diversifying the export assortment and raising the share of goods of the classic brand "UZtextile";

- In conjunction with local district, city and regional Khokimiyats to create marketing research centers that provide manufacturers with the necessary market information;

- Achieve the inclusion in the state scientific research topics on the development of theoretical, methodological and practical foundations of the Uzbek brand of textiles, as well as the problems of its promotion in world markets, the development of the fashion industry in the Republic and other topical issues;

- Organize permanent courses to improve the qualifications of specialists in design, engineering, and marketing;

- The basics of introducing international quality management for the specifics of the production of export goods for world markets.

\section{References}

1. Smith A (1993) Research on the nature and the wealth of nations. Science.

2. Ricardo D (2007) Fundamentals of political economy and taxation-Trans. Eksmo.

3. Mill S (1981) Fundamentals of political economy -Per Progress.

4. Herschel E, Olin B (2006) The Impact of Foreign Trade on the Income Distribution - Moscow TEIS.

5. Samuelson P (1992) Economy T. Algon VNIISI.

6. Leontev $\vee(2006)$ Domestic production and foreign trade: a new study of the positions of American capital. Moscow TEIS.

7. Porter M (1993) International Competition-Moscow "International Relations".

8. Boltaboyev M (2005) Marketing strategy in the development of export opportunities of the textile industry of the Republic of Uzbekistan. Dan Diss Autoref $\mathrm{T}$.

9. Odilova Z (2008) Marketing strategy for exporting products to international markets. Dan Diss Autoref T.

10. Rakhmonov R (2012) Rational use of the export potential of the Fergana region and ways to improve it. Diss Autoref $T$.

11. Dilyafruz N (2010) Uzbekistan: Forming a cluster strategy for textile industry development.

12. Uzbekistan National News Agency (2018) Development strategy of Uzbekistan textile industry and international cooperation.

13. Spindles Al (2017) Regional features of the investment activities of small and medium-sized businesses. Trends of Development of Science and Education.

14. Bessonova LP (2017) Improving the competitiveness of catering on the basis of the QFD methodology. Scientific Dialogue: Economics and Management. 